\title{
Electricity Production in Microbial Fuel Cell Subjected to Different Operational Modes
}

\author{
Hong-Yan Dai ${ }^{1,2} \cdot$ Hui-Min Yang ${ }^{1} \cdot$ Xian Liu $^{1} \cdot$ Xuan Jian $^{1} \cdot$ Zhen-Hai Liang $^{1}$
}

Received: 1 December 2015/Revised: 28 January 2016/Published online: 2 May 2016

(C) The Chinese Society for Metals and Springer-Verlag Berlin Heidelberg 2016

\begin{abstract}
The effects of inoculum species, substrate concentration, temperature, and cathodic electron acceptors on electricity production of microbial fuel cells (MFCs) were investigated in terms of start-up time and power output. When inoculated with aeration tank sludge, this MFC outperformed the cell that was inoculated with anaerobic sludge in terms of start-up time and power output. After running for a certain time period, the dominant populations of the two MFCs varied significantly. Within the tested range of substrate concentration (200-1800 $\left.\mathrm{m} \mathrm{L}^{-1}\right)$, the voltage output increased and the time span of the electricity generation lengthened with increasing substrate concentration. As the temperature declined from 35 to $10{ }^{\circ} \mathrm{C}$, the maximum power density reduced from 2.229 to $1.620 \mathrm{~W} \mathrm{~m}^{-3}$, and anodic polarization resistance correspondingly dropped from 118 to $98 \Omega$. The voltage output of $\mathrm{MFC}-\mathrm{Cu}^{2+}$ was $0.447 \mathrm{~V}$, which is slightly lower than that achieved with MFC- $\left[\mathrm{Fe}(\mathrm{CN})_{6}\right]^{3-}(0.492 \mathrm{~V})$, thereby indicating that MFCs could be used to treat wastewater containing $\mathrm{Cu}^{2+}$ pollutant in the cathode chamber with removal of organics in anode chamber and simultaneous electricity generation.
\end{abstract}

KEY WORDS: Microbial fuel cells; Inoculum species; Cathodic electron acceptors; Electricity production

\section{Introduction}

With the dwindling of fossil fuels and aggravation of global environmental pollution, the demand for renewable clean energy is sharply increasing [1,2]. The microbial fuel cell (MFC), an innovative device that can generate electricity and treat organic wastewater at the same time, has been attracting much attention in past 10 years [3-5]. In the initial stage, the electric production efficiency of MFC

Available online at http://link.springer.com/journal/40195.

Zhen-Hai Liang

liangzhenhai@tyut.edu.cn; liangzhenh@sina.com

1 College of Chemistry and Chemical Engineering, Taiyuan University of Technology, No. 79 West Yingze Street, Taiyuan 030024, Shanxi, China

2 Department of Environmental Engineering, Taiyuan College, Taiyuan 030032, China is extremely low at a few milliwatts per square meter [6]. Most of the works were conducted to promote the performance of MFC (mainly power output) during the last decade. Numerous operating parameters, such as microbial activity [7], the type and concentration of organic matter [8], temperature [9], $\mathrm{pH}$ value [10], electrode materials [11, 12], cathodic electron acceptors [13, 14], and internal resistance $[15,16]$, affect the power output.

As inocula of MFC, mixed microbial communities outperform pure cultures because of their stability, excellent adaptability to the environment, and synergistic effect between microbial species [17]. Moreover, the performance varied among MFCs inoculated by mix cultures from different sources or different sampling locations of the same effluent [18]. Numerous researchers used anaerobic microorganisms as inocula of MFCs, and aerobic microorganisms were rarely used as inocula in this regard.

In addition, the cathodic electron acceptor is another important parameter that influences the power output of 
MFCs. Oxygen has been widely used as an electron acceptor in most MFCs because of its high redox potential and unlimited availability. However, poor oxygen reduction kinetics restricts the performance of the oxygen cathode, and expensive catalysts are conventionally required (e.g., platinum-based catalysts). Potassium ferricyanide is another widely used as an electron acceptor in dualchamber MFCs, but the use of this acceptor will incur an increase in cost and induce environment pollution. Therefore, long-term use of potassium ferricyanide as cathodic electron acceptor in MFCs is unrealistic [19]. Some heavy metals, such as hexavalent chromium ( $\mathrm{Cr}(\mathrm{VI}))$, pentavalent vanadium $(\mathrm{V}(\mathrm{V}))$, tetravalent selenium (Se(IV)), bivalent copper $(\mathrm{Cu}(\mathrm{II}))$, bivalent mercury $(\mathrm{Hg}(\mathrm{II}))$, and univalent silver $(\mathrm{Ag}(\mathrm{I}))$, from mining and metallurgical wastewaters and leachates possess high redox potential. When used as cathodic electron acceptors in dual-chamber MFCs and reduced at the cathode chamber, these heavy metals are removed from waste streams [20] and recycled.

In this study, the effects of four factors on the performance of MFCs were investigated in terms of start-up time and power output. The four factors included the following: (1) two inoculum species, namely, anaerobic microorganisms and aerobic microorganisms; (2) five concentrations of sodium acetate $(\mathrm{NaAc})$; (3) different temperature levels (35 and $10{ }^{\circ} \mathrm{C}$ ); and (4) two kinds of electron acceptors: $\mathrm{K}_{3}\left[\mathrm{Fe}(\mathrm{CN})_{6}\right]$ and $\mathrm{CuCl}_{2}$. This study aims to clarify relevant factors and optimize the performance of MFCs.

\section{Materials and Methods}

\subsection{MFC Configuration}

A dual-chamber MFC composed of two glass bottles was used in this study. The bottles, which contained $90 \mathrm{~mL}$ operating volume each, served as the anode and cathode chambers. The bottles are connected by sidearms and separated by a cation exchange membrane $\left(4.5 \mathrm{~cm}^{2}\right.$, JCMII, Yanrun membrane Co., Ltd., Beijing, China). The anode was carbon felt $(2 \mathrm{~cm} \times 4 \mathrm{~cm} \times 1 \mathrm{~cm})$, while the cathode was a stainless steel mesh $(2 \mathrm{~cm} \times 4 \mathrm{~cm} ; \mathrm{Fe}, 70.6 \%$; $\mathrm{Cr}$, $18.3 \%$; Ni, 8.5\%; Si, $0.8 \%$; $\mathrm{Mn}, 1.8 \%$; wire diameter, 120-150 $\mu \mathrm{m}$; and pore size, 450-525 $\mu \mathrm{m})$. Electrodes were connected with concealed copper wire, and an external load resistance (1000 $\Omega$ ) was linked to the circuit. The Ag/ $\mathrm{AgCl}$ reference electrode $(+0.197 \mathrm{~V}$ vs. SHE) was inserted into the chamber for measuring electrode potential.

\subsection{Start-up and Measurement}

The aeration tank sludge and anaerobic sludge used as inoculum species were collected from the Yangjiapu wastewater treatment plant for municipal sewage in Taiyuan, China. Prior to inoculation into MFC, the microbes were cultured anaerobically for 2 days. Then, $20 \mathrm{~mL}$ inocula and $60 \mathrm{~mL}$ anolyte were poured into the anode chamber. The aeration tank sludge was inoculated into MFC-A, and the anaerobic sludge was inoculated into MFC-B. The anolyte was prepared as follows: $1300 \mathrm{mg}$ $\mathrm{NaAc}$ (except for the substrate concentration test), $130 \mathrm{mg}$ $\mathrm{KCl}, \quad 310 \mathrm{mg} \quad \mathrm{NH}_{4} \mathrm{Cl}, \quad 6640 \mathrm{mg} \quad \mathrm{NaH}_{2} \mathrm{PO}_{4} \cdot 2 \mathrm{H}_{2} \mathrm{O}$, $20,640 \mathrm{mg} \mathrm{Na}_{2} \mathrm{HPO}_{4} \cdot 12 \mathrm{H}_{2} \mathrm{O}$, and $2 \mathrm{mg} \mathrm{NaCl}$ were dissolved in distilled water. Then $20 \mathrm{~mL}$ trace mineral element solution was poured into the solution. Finally, the solution was diluted to $1 \mathrm{~L}$. To prepare the catholyte, $5844 \mathrm{mg} \mathrm{NaCl}$ and $32,925 \mathrm{mg} \mathrm{K}_{3}\left[\mathrm{Fe}(\mathrm{CN})_{6}\right]$ (except for the electron acceptor test)were dissolved in distilled water, and then the solution was diluted to $1 \mathrm{~L}$. All MFCs were operated in fed-batch mode in a temperature-controlled chamber at $35^{\circ} \mathrm{C}$, except for the temperature test. The device was not stirred during the entire experiment, and sludge settled at the bottom of the anode chamber. As the voltage output of MFCs was below $0.05 \mathrm{~V}$, the catholyte was replaced completely, and $60 \mathrm{~mL}$ of anode supernatant was replaced.

The voltage of the MFC across a $1000 \Omega$ external resistor (ZX21A, Zhengtao instrument Co., Shanghai, China) was recorded every $30 \mathrm{~min}$ with a multimeter (UNI-T 803; Uni-Trend Electronics Co., Ltd., Shanghai, China). Polarization curves were obtained by varying the external resistance over a range from 10000 to $20 \Omega$ when the voltage output approached a steady and repeatable state. Current density $\left(I_{\mathrm{V}}\right)$ and power density $\left(P_{\mathrm{V}}\right)$ were obtained according to the formula $I_{\mathrm{V}}=E / R V$ and $P_{\mathrm{V}}=E I / V$, where $E$ is the voltage output, $R$ is the external resistance, $I$ is the current, and $V$ is the working volume of the cathode chamber. Electrochemical impedance spectroscopy (EIS), which was used to characterize electrochemical capability, was performed in an electrochemical workstation (Princeton Applied Research, USA) with a three electrode system consisting of a working electrode (bioanode), a counter electrode (cathode), and a reference electrode $(\mathrm{Ag} / \mathrm{AgCl})$. EIS tests were conducted under the condition of open circuit voltage with a potential amplitude of $10 \mathrm{mV}$ over a frequency range of $100 \mathrm{kHz}-10 \mathrm{mHz}$.

The surface morphologies of bioanode were observed by a thermal field emission scanning electron microscope (SEM, JSM-7001F, JEOL, Japan). First, a small piece of carbon felt was cut off from bioanode using scissors. Second, the samples were fixed with a $2.5 \%$ glutaraldehyde in $0.1 \mathrm{~mol} \mathrm{~L}^{-1}$ phosphate buffer for $1.5 \mathrm{~h}$ at $4{ }^{\circ} \mathrm{C}$ and washed using a $0.1 \mathrm{~mol} \mathrm{~L}^{-1}$ phosphate buffer solution. Third, the fixed specimens were gradually dehydrated with ethanol 30, 50, 70, 80, 90, 100\% solutions (each for $15 \mathrm{~min}$ ) and $\mathrm{CO}_{2}$ critical point dried. Finally, the 
specimens were coated with Au before SEM observation. The SEM measurement was taken at $10 \mathrm{keV}$ acceleration potential. Anodic microbial species were identified by high-throughput-macro genome sequencing technology. First, the anode carbon felt was rinsed with deionized water to remove the residual sludge. Then, the top, middle, and bottom sections of the anode were cut, fragmented, and mixed for DNA extraction [21]. Total genomic DNA was extracted by using EZNA Soil DNA Kit according to the manufacturer's instruction. The quantity and quality of extracted DNA were checked using Qubit2.0 DNA detection kit. The V3-V4 region (length of $464 \mathrm{bp}$ ) of the bacterial 16S rRNA gene was amplified using the universal primers $341 \mathrm{~F}$ (5'-CCTACGGGNGGCWGCAG-3') and 805R (5'-GACTACHVGGGTATCTAATCC- $\left.3^{\prime}\right)$. Highthroughput-macro genome sequencing was carried out according to standard protocols. To analyze the microbial community structure and bacterial diversity, we phylogenetically allocated sequences down to the genus level by using the RDP Classifier software.

The elemental composition of deposits covered on the stainless steel mesh cathode was measured using SEM equipped with an auxiliary X-ray energy-dispersive spectrometry (EDS, QUANTAX 200, Germany). The EDS measurement was taken at $15 \mathrm{keV}$ acceleration potential.

\section{Results and Discussion}

\subsection{Effects of Inoculum Species}

Microorganisms possess a variety of enzymes that catalyze specific reaction in biological systems. Certain electrochemically active redox enzymes, such as cytochromes, can transport electrons to external materials [22]. Many microorganisms existing in the mix culture possess the electrochemically active redox enzymes and could be used as inoculum species of mediator-less MFC. However, the electrogenesis capacity of the mix culture varies among different sources. In order to examine the electricity generation by different mixed microbial communities, aeration tank sludge and anaerobic sludge were, respectively, inoculated to identical MFCs (MFC-A for aeration tank sludge and MFC-B for anaerobic sludge) to test the start-up time and the power output. Start-up time is the required time for MFCs to reach a stable voltage during start-up. Despite that the same volume of inocula was inoculated into the MFCs, the start-up times of the two MFCs were different. The start-up time of MFC-A, which used aeration tank sludge as inoculum, was 10 days. This duration was shorter than that of MFC-B (14 days), with anaerobic sludge as inoculum. After the second replacement of the anolyte and catholyte, the voltage output of all MFCs increased. The maximum voltage output values obtained with a fixed resistance of $1000 \Omega$ during the start-up period were $0.4 \mathrm{~V}$ (MFC-A) and $0.31 \mathrm{~V}$ (MFC-B).

Polarization data obtained after the start-up period show that different maximum power densities could be produced as a result of different inoculum species (Fig. 1). The maximum power density of $2.229 \mathrm{~W} \mathrm{~m}^{-3}$ produced by MFC-A was higher than that produced by MFC-B $\left(1.201 \mathrm{~W} \mathrm{~m}^{-3}\right)$. According to Ohm's law, as the internal resistance equaled the external resistance, the maximum power output is obtained [23], and the power density reaches a peak on the curve. As seen in Fig. 1, the internal resistance of MFC-A as calculated from polarization curves was $800 \Omega$. The internal resistance of MFC-B was $1000 \Omega$, which was $200 \Omega$ higher than that of MFC-A. Under different bacterial inoculation conditions, the anode resistance is the major factor that affects the whole MFC internal resistance. The aeration tank sludge as inoculum resulted in the reduction in anode internal resistance and the consequent increase in power output in comparison with anaerobic sludge.

Anodes were removed after operating for 2 months. Surface morphologies were observed under a scanning electron microscope, and the microbial species were measured by high-throughput-macro genome sequencing technology, which could provide significant insight into the microbial community structures in bioelectrochemical systems (Fig. 2).

As seen in Fig. 2a, b, the anode carbon felts of MFCs were covered by rod-shaped bacteria regardless of which mix culture was inoculated into MFCs. The rod-shaped bacteria were approximately $0.3-0.5 \mu \mathrm{m}$ in width and $1.0-1.5 \mu \mathrm{m}$ in length. Moreover, bacteria appeared as

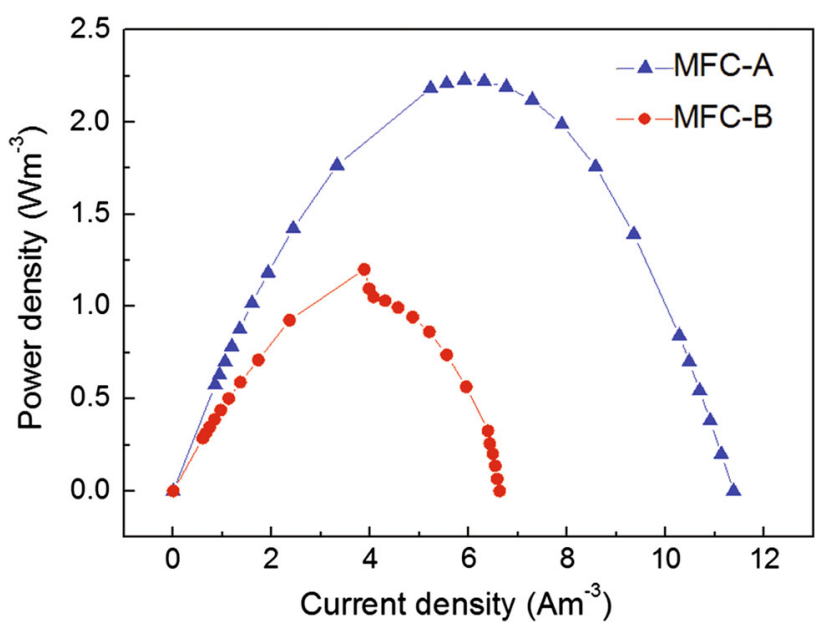

Fig. 1 Power density curves of MFCs inoculated by different microbials (MFC-A for aeration tank sludge and MFC-B for anaerobic sludge). Polarization curves were obtained by varying the external resistance over a range from 10,000 to $20 \Omega$ 

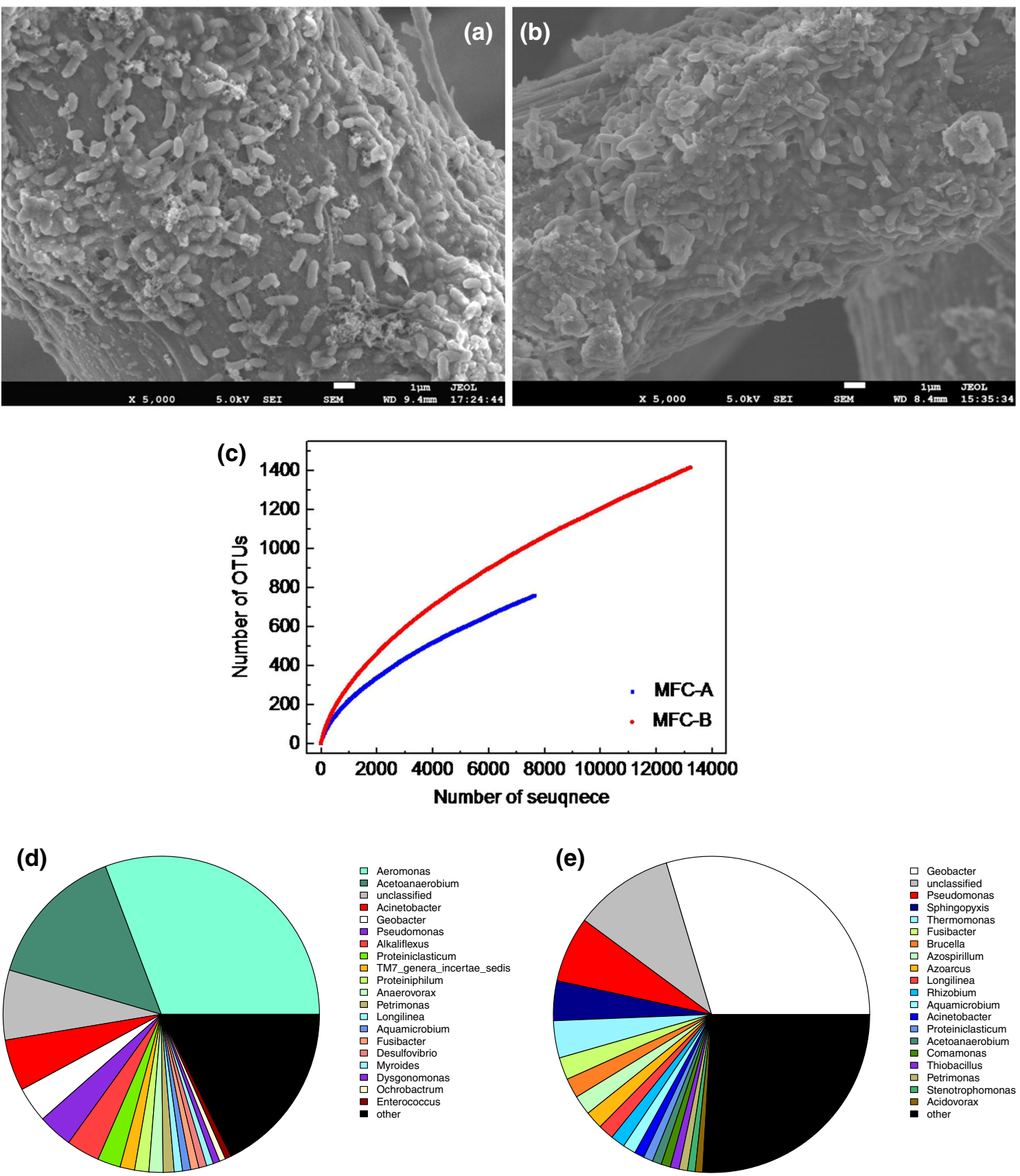

Fig. 2 SEM micrographs (a for MFC-A and b for MFC-B). Rarefaction curves $\mathbf{c}$ and the taxonomic classification of pyrosequences from bacterial communities at genus level (d for MFC-A and e for MFC-B). The OTUs were defined 3\% distances

individual cells without substantial extracellular material, and all cells were in actual physical contact with the electrode.

Richness analysis using 16S rRNA gene-based highthroughput sequencing was shown in Fig. 2c. We obtained 760 (MFC-A) and 1417 (MFC-B) operational taxonomic units (OTUs) at a $3 \%$ distance. The total numbers of OTUs estimated by Chao1 estimator were 2037 (MFC-A) and 3243 (MFC-B), indicating that MFC-B had the greatest richness than MFC-A. The Shannon index of MFC-B (4.97) was also larger than 4.14 in MFC-A. Compared with other MFCs which were fed complex substrates [24], the biodiversity of MFC-A and B was lower, because both of them used $\mathrm{NaAc}$ as the substrate.

Community analysis shows that the two communities present an extremely high diversity (Fig. 2d, e). In MFC-A, the majority of dominant populations belonged to Aeromonas $(30.75 \%)$ and Acetoanaerobium (14.73\%), whereas 
these two kinds of bacteria accounted for only $0.28 \%$ and $0.94 \%$ in MFC-B, respectively. Aeromonas are facultative anaerobic microorganisms, and Acetoanaerobium are anaerobic bacteria. Though it is not clear their specific function, they might have contribution to electricity generation in MFCs. Geobacter [25] and Pseudomonas [18], which are well-known exoelectrogenic bacteria, occupied $3.63 \%$ and $3.54 \%$ in MFC-A, respectively. In MFC-B, Geobacter (29.62\%) and Pseudomonas (6.73\%) were the dominant populations. Shewanella [26], another wellknown exoelectrogenic bacteria, only occupied $0.13 \%$ in MFC-A and was not found in MFC-B. In addition, 7.42\% (MFC-A) and $10.03 \%$ (MFC-B) were not classified at the genus level, indicating that these bacteria are unknown. Thus, numerous kinds of bacteria in nature possess electronic activity, and exoelectrogenic bacteria vary because of different sources.

\subsection{Effect of Substrate Concentration}

The substrate concentration plays an important role in controlling the performance of MFCs. To study the effect of substrate concentration on the power output, a series of substrate concentrations ranging from 200 to $1800 \mathrm{mg} \mathrm{L}^{-1}$ were tested in MFC-A in terms of voltage output and the time span of electricity generation. The time span is the time interval between the twice replacements of anolyte and catholyte. The same operations were repeated thrice to ensure that a stable trend was achieved.

The experimental results are presented in Fig. 3. It could be seen from Fig. 3a, b, voltage output increased, and the time span of electricity generation increased with increasing substrate concentration. As the concentration increased within a low range $\left(\leq 1000 \mathrm{mg} \mathrm{L}^{-1}\right)$, the maximum voltage output and time span of electricity generation increased drastically.
Meanwhile, at high concentration $\left(>1000 \mathrm{mg} \mathrm{L}^{-1}\right)$, the maximum voltage output and time span of electricity generation experienced a moderate increase with increasing concentration. For instance, when the concentration of $\mathrm{NaAc}$ was $200 \mathrm{mg} \mathrm{L}^{-1}$, the maximum voltage output was only $(0.423 \pm 0.012) \mathrm{V}$. After $(16 \pm 0.5) \mathrm{h}$, the voltage output decreased to below $0.05 \mathrm{~V}$. As the concentration of NaAc increased to $1000 \mathrm{mg} \mathrm{L}^{-1}$, the maximum voltage output and time span of electricity generation were $(0.472 \pm 0.011) \mathrm{V}$ and $(42 \pm 1) \mathrm{h}$, respectively. Meanwhile, the maximum voltage output $[(0.483 \pm 0.008) \mathrm{V}]$ and the longest time span of electricity generation $[(60 \pm 1.5) \mathrm{h}]$ were obtained at a concentration of $1800 \mathrm{mg} \mathrm{L}^{-1}$. According to the results obtained by other researchers, when the substrate concentration increases in the low concentration range, the power output exhibits a significant increase, whereas a decrease in power output is observed as the substrate concentration reaches a certain amount [27]. In this study, the phenomenon of voltage drop did not appear because the substrate concentration did not reach the amount.

\subsection{Effect of Temperature}

The temperature strongly influenced the performance of MFCs because of the following explanations: (1) The nature and distribution of the microbial community are influenced by temperature (the optimum temperatures for different species varied); (2) the electrode potentials and the free Gibbs energy of reactions are influenced by temperature; (3) the activation energy, mass transfer coefficient, and conductivity of the solution are under the influence of temperature, as well [28]. To date, the great majority of MFC studies have been conducted at temperatures between 20 and $35^{\circ} \mathrm{C}$, with the actual operation temperature being selected according to the respective
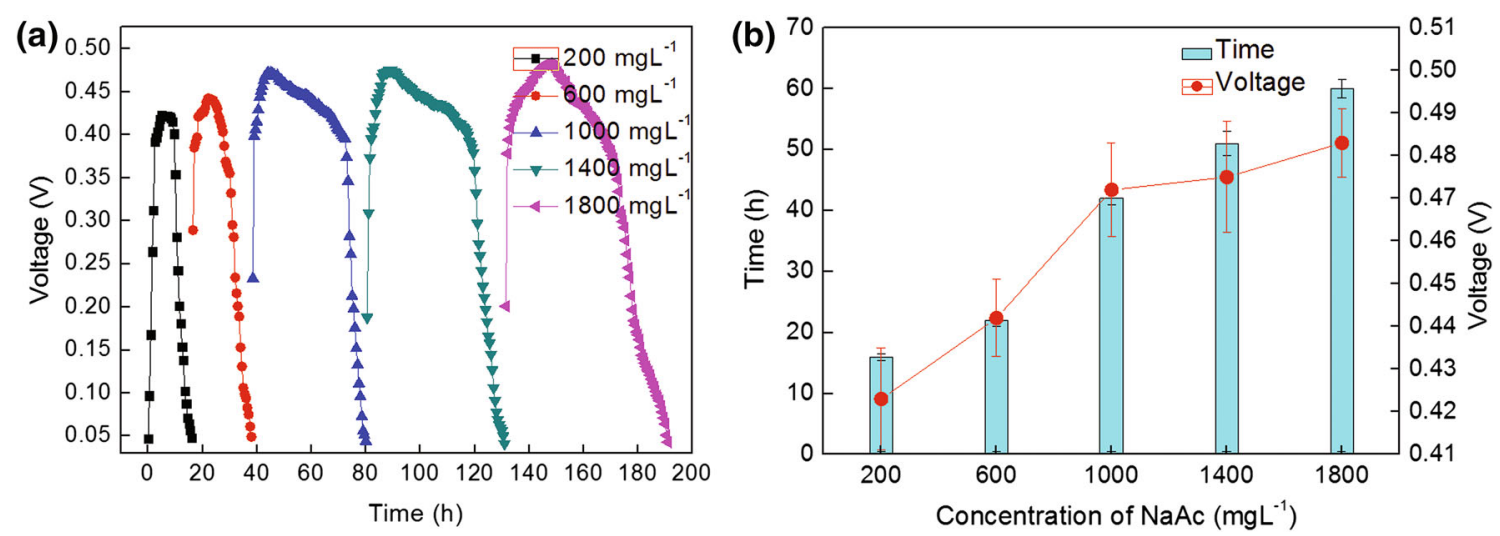

Fig. 3 a Discharge curve of MFC with different NaAc concentrations (200, 600, 1000, 1400, $\left.1800 \mathrm{mg} \mathrm{L}^{-1}\right)$. b The maximum voltage output and time span of electricity generation of MFCs with different NaAc concentrations. A load resistor is $1000 \Omega$. The measurements were taken in triplicate and treated statistically 
laboratory standard. In this study, after starting up at $35^{\circ} \mathrm{C}$, two identical MFCs were operated at different operation temperature values. One MFC was still operated at $35{ }^{\circ} \mathrm{C}$, whereas the other operated at $10{ }^{\circ} \mathrm{C}$. When the voltage was approximately constant at each temperature, polarization and EIS were carried out. The results for MFCs are illustrated in Fig. 4.

In general, microbial metabolism and membrane permeability are enhanced with a moderate temperature increase [29]. Consequently, the performance of MFCs would be improved. Figure $4 \mathrm{a}$ compares the polarization curves obtained from MFC- 35 and MFC- $10{ }^{\circ} \mathrm{C}$, respectively. It was found that with decreasing temperature from 35 to $10{ }^{\circ} \mathrm{C}$ the MFCs showed an insignificant change in open circuit voltage (from 0.72 to $0.689 \mathrm{~V}$ ) and $I_{\max }$ (from 11.375 to $11.1 \mathrm{~A} \mathrm{~m}^{-3}$ ). However, the MFC- $35{ }^{\circ} \mathrm{C}$ produced a maximum power density of $2.229 \mathrm{~W} \mathrm{~m}^{-3}$, which is approximately $\sim 1.4$ times of that obtained with the MFC- $10{ }^{\circ} \mathrm{C}\left(1.620 \mathrm{~W} \mathrm{~m}^{-3}\right)$.

To better understand the influence of temperature on the MFCs, EIS experiments were conducted for all anodes at the open circuit potential, and the Nyquist plots are shown in Fig. 4b. In the high-frequency region, the intercept of the curve and the real axis could be regarded as ohmic resistance $\left(R_{\mathrm{ohm}}\right)$, which is affected by the electrode material, wire connection to the external circuit, and the electrolyte [30]. The $R_{\mathrm{ohm}}$ values for anode of MFC-35, MFC- $10{ }^{\circ} \mathrm{C}$ are approximately 0.65 and $0.55 \Omega$ (inset of Fig. 4b), respectively. In the low-frequency region, the diameter of the semicircle could be regarded as charge-transfer resistance $\left(R_{\mathrm{ct}}\right)$ occurring at the anode. The $R_{\mathrm{ct}}$ for anode of MFC- $35{ }^{\circ} \mathrm{C}$ was estimated to be $118 \Omega$, whereas the value for MFC- $10{ }^{\circ} \mathrm{C}$ was $98 \Omega$, indicating that the anodic resistance decreased by reducing the cell temperature. This conclusion was consistent with that of Liu et al. [31].

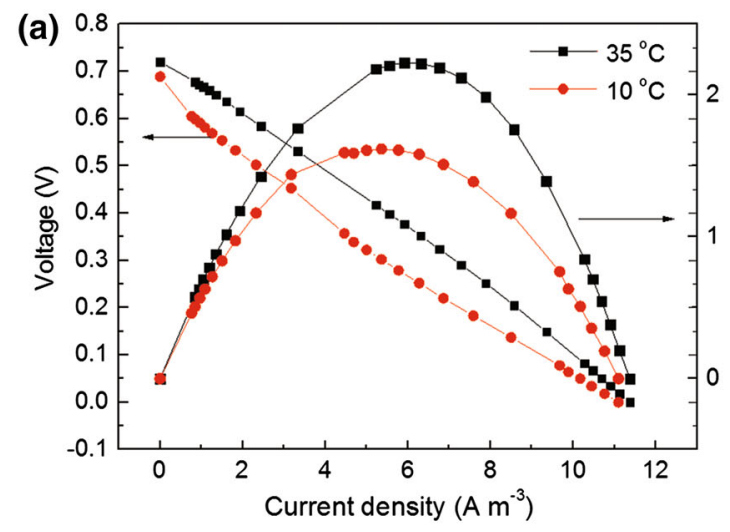

\subsection{Effect of Cathodic Electron Acceptor}

The performance of the MFC is improved by using ferricyanide as cathodic electron acceptor [22]. However, $\mathrm{K}_{3-}$ $\left[\mathrm{Fe}(\mathrm{CN})_{6}\right]$ is toxic and chemically unstable. When $\mathrm{K}_{3}\left[\mathrm{Fe}(\mathrm{CN})_{6}\right]$ is under acidic condition, poisonous hydrocyanic acid could be produced. Therefore, the operation with $\mathrm{K}_{3}\left[\mathrm{Fe}(\mathrm{CN})_{6}\right]$ solution in MFC presents potential safety risks. In general, substances with high redox potential could be used as cathodic electron acceptors in MFC. Certain heavy metal ions that are sourced from mining and metallurgical wastewaters possess high redox potential. The standard electrode potential of $\mathrm{Cu}^{2+} / \mathrm{Cu}$ is $0.340 \mathrm{~V}$ [Eq. (1)], which is slightly lower than that of $\left[\mathrm{Fe}(\mathrm{CN})_{6}\right]^{3-} /\left[\mathrm{Fe}(\mathrm{CN})_{6}\right]^{4-}[0.430 \mathrm{~V}$, Eq. (2)]. When used as cathodic electron acceptor, $\mathrm{Cu}^{2+}$ could be removed and recycled from wastewater.

$\mathrm{Cu}^{2+}+2 \mathrm{e}=\mathrm{Cu} E^{\circ}=0.340 \mathrm{~V}$.

$\left[\mathrm{Fe}(\mathrm{CN})_{6}\right]^{3-}+\mathrm{e}^{-}=\left[\mathrm{Fe}(\mathrm{CN})_{6}\right]^{4-} E^{\circ}=0.430 \mathrm{~V}$.

In this study, two cathodic electron acceptors $\left(\mathrm{K}_{3}\left[\mathrm{Fe}(\mathrm{CN})_{6}\right]\right.$ and $\left.\mathrm{CuCl}_{2}\right)$ were tested under the same working conditions, i.e., using of aeration tank sludge as inoculum and $\mathrm{NaAc}\left(1300 \mathrm{mg} \mathrm{L}^{-1}\right)$ as substrate. The catholytes for two MFCs were prepared as $100 \mathrm{mM} \mathrm{K}_{3}\left[\mathrm{Fe}(\mathrm{CN})_{6}\right]+100 \mathrm{mM} \mathrm{NaCl}$ for one $(\mathrm{MFC}-$ $\left.\left[\mathrm{Fe}(\mathrm{CN})_{6}\right]^{3-}\right)$ and $100 \mathrm{mM} \mathrm{CuCl}{ }_{2}+100 \mathrm{mM} \mathrm{NaCl}$ for another $\left(\mathrm{MFC}-\mathrm{Cu}^{2+}\right)$. Throughout the test, $\mathrm{pH}$ was not adjusted.

After start-up, anode potentials of the two MFCs were observed to be around $(-0.450 \pm 0.005) \mathrm{V}$ with respect to the $\mathrm{Ag} / \mathrm{AgCl}$ reference electrode, indicating that bioelectrocatalytic activity is not influenced by cathodic electron acceptors. The performance of MFCs with different cathodic electron acceptors was evaluated by monitoring

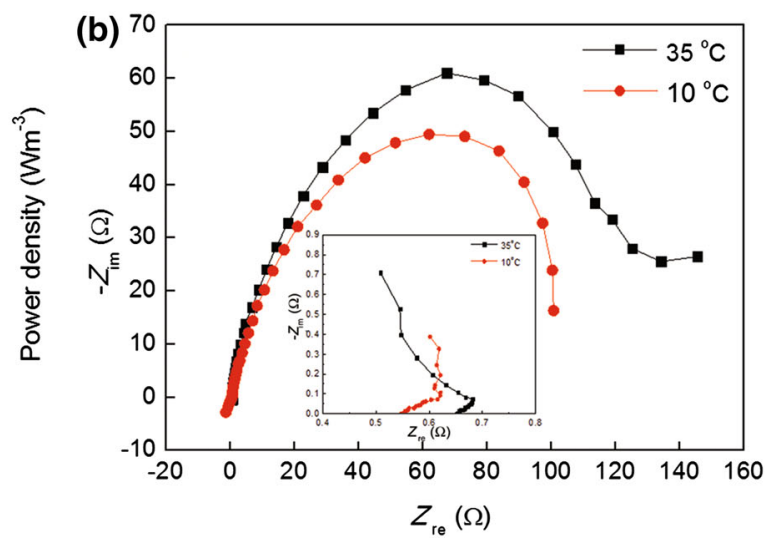

Fig. 4 Performance of MFCs at different reactor temperatures $\left(35\right.$ and $\left.10{ }^{\circ} \mathrm{C}\right)$ : a polarization curves and power density curves; $\mathbf{b}$ Nyquist plots for anodes. The insert illustrates the high-frequency part of the result. EIS tests were conducted under the condition of open circuit voltage with a potential amplitude of $10 \mathrm{mV}$ over a frequency range of $100 \mathrm{kHz}-10 \mathrm{mHz}$ 


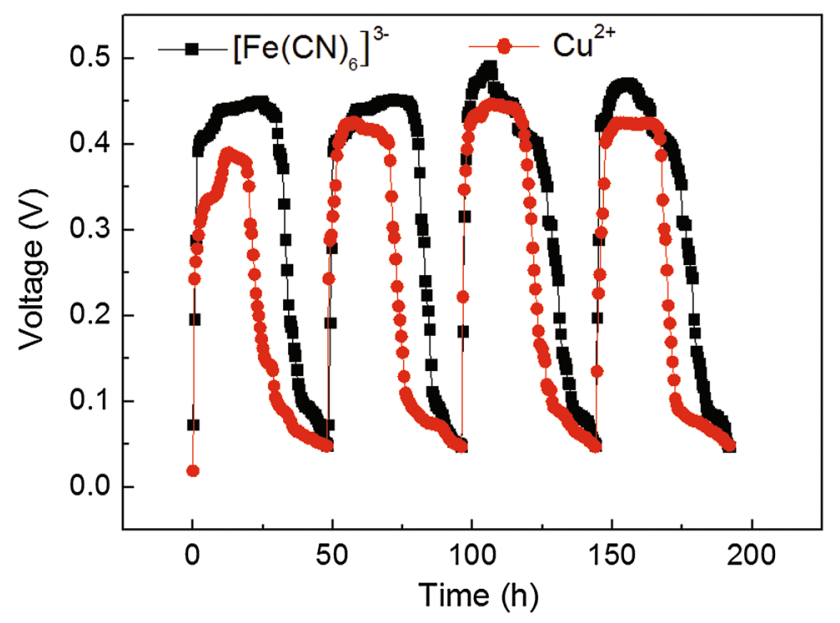

Fig. 5 Voltage output curves of the MFCs with different electron acceptors $\left(\mathrm{Cu}^{2+}\right.$ and $\left.\left[\mathrm{Fe}(\mathrm{CN})_{6}\right]^{3-}\right)$ in closed circuit mode (load resistor is $1000 \Omega$ )

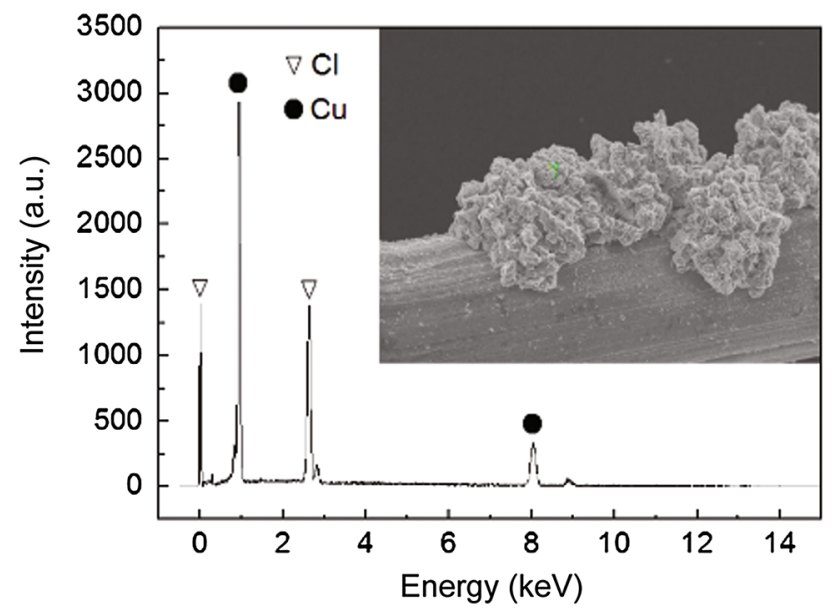

Fig. 6 EDS spectrum of the deposits on the cathode surface (insert)

voltage output. Figure 5 shows a typical voltage generation profile, as observed in numerous MFC configurations [32]. The voltage output of the two MFCs rapidly increased after anolyte and catholyte replacement, and reached relatively stable values, and eventually dropped because of substrate depletion at the anode chamber (NaAc was almost undetectable in the effluent). The profile was reproducible when fresh substrate was poured into the anode. The MFCs were operated for over $196 \mathrm{~h}$, with insignificant variations in voltage output, suggesting the long-term stability of these systems. MFC $-\mathrm{Cu}^{2+}$ delivered a maximum stable voltage output of $0.447 \mathrm{~V}$, which was slightly lower than that achieved with MFC- $\left[\mathrm{Fe}(\mathrm{CN})_{6}\right]^{3-}(0.492 \mathrm{~V})$. The obtained voltage output was comparable to the results achieved with $\mathrm{K}_{3}\left[\mathrm{Fe}(\mathrm{CN})_{6}\right]$ and other well-performing cathode systems that use oxygen [33]. At the end of the experiment, some reddish-brown sediments were deposited at the cathode surface of MFC- $-\mathrm{Cu}^{2+}$. Figure 6 shows the EDS spectrum of the deposits. The $\mathrm{Cu}$ content in the deposits is 55.85 at $\%$ and the $\mathrm{Cl}$ is 44.15 at\%, indicating that a fraction of $\mathrm{Cu}^{2+}$ was reduced to $\mathrm{Cu}$. MFCs could be used to treat wastewater containing $\mathrm{Cu}^{2+}$ pollutants in cathode chamber with removal of organics in anode chamber and simultaneous electricity generation.

\section{Conclusions}

In this study, the effects of four factors (inoculum species, substrate concentration, temperature, and cathodic electron acceptor) on the performance of MFCs were investigated. When the MFC was inoculated with aeration tank sludge, it outperformed the MFC inoculated with anaerobic sludge in terms of start-up time and power output. After operating for a period of time, the dominant populations of the two MFCs varied significantly. The maximum voltage output and the time span of electricity generation showed a moderate increase as the substrate concentration increased. As the temperature decreased from 35 to $10^{\circ} \mathrm{C}$, the maximum power density decreased from 2.229 to $1.620 \mathrm{~W} \mathrm{~m}^{-3}$, and anodic polarization resistance correspondingly dropped from 118 to $98 \Omega$. Using $\mathrm{Cu}^{2+}$ as electron acceptor, the MFC could deliver a maximum stable voltage output of $0.447 \mathrm{~V}$, which was slightly lower than that achieved with MFC- $\left[\mathrm{Fe}(\mathrm{CN})_{6}\right]^{3-}(0.492 \mathrm{~V})$.

Acknowledgments This work was financially supported by the National Natural Science Foundation of China and Shenhua Group Corp. (Grant No. U1261103).

\section{References}

[1] R. Haase, R. Müller, D. Landgrebe, P. Scholz, M. Riemer, Acta Metall. Sin. (Engl. Lett.) 28, 1518 (2015)

[2] D. Maheswari, P. Venkatachalam, Acta Metall. Sin. (Engl. Lett.) 28, 354 (2015)

[3] Z.S. Lv, D.H. Xie, F.S. Li, Y. Hu, C.H. Wei, C.H. Feng, J. Power Sources 246, 642 (2014)

[4] R.D. Cusick, P.D. Kiely, B.E. Logan, Int. J. Hydrog. Energy 35, 8855 (2010)

[5] C.T. Wang, W.J. Chen, R.Y. Huang, Int. J. Hydrog. Energy 35, 7217 (2010)

[6] B.E. Logan, C. Murano, K. Scott, N.D. Gray, I.M. Head, Water Res. 39, 942 (2005)

[7] D. Juang, APCBEE Proced. 1, 2 (2012)

[8] S.B. Velasquez-Orta, I.M. Head, T.P. Curtis, K. Scott, Bioresour. Technol. 102, 5105 (2011)

[9] A. Patil Sunil, F. Harnisch, B. Kapadnis, U. Schröder, Biosens. Bioelectron. 26, 803 (2010)

[10] S. Puig, M. Serra, M. Coma, M. Cabré, M.D. Balaguer, J. Colprim, Bioresour. Technol. 101, 9594 (2010)

[11] Y.Q. Wang, B. Li, L.Z. Zeng, D. Cui, X.D. Xiang, W.S. Li, Biosens. Bioelectron. 41, 582 (2013) 
[12] S.L. Chen, G.H. He, S.J. He, U. Schröder, H.Q. Hou, Biosens. Bioelectron. 34, 282 (2012)

[13] D.A. Jadhav, D.A. Ghadge, D. Mondal, M.M. Ghangrekar, Bioresour. Technol. 154, 330 (2014)

[14] L.L. Wei, H.L. Han, J.Q. Shen, Int. J. Hydrog. Energy 37, 12980 (2012)

[15] R.A. Timmers, D.P. Strik, H.V. Hamelers, C.J. Buisman, Electrochim. Acta 72, 165 (2012)

[16] P.Y. Zhang, Z.L. Liu, J. Power Sources 195, 8013 (2010)

[17] V.R. Nimje, C.Y. Chen, H.R. Chen, C.C. Chen, Y.M. Huang, M.J. Tseng, K.C. Cheng, Y.F. Chang, Bioresour. Technol. 104, $315(2012)$

[18] S.F. Ketep, A. Bergel, M. Bertrand, W. Achouak, E. Fourest, Biochem. Eng. J. 73, 12 (2013)

[19] L.X. Zhang, C.S. Liu, L. Zhuang, W.S. Li, S.G. Zhou, J.T. Zhang, Biosens. Bioelectron. 24, 2825 (2009)

[20] Y.X. Liu, J.Y. Shen, L.P. Huang, D. Wu, J. Hazard. Mater. 262, 1 (2013)

[21] L. Lu, D.F. Xing, N.Q. Ren, Water Res. 46, 2425 (2012)

[22] Z.D. Liu, H.R. Li, Biochem. Eng. J. 36, 209 (2007)

[23] Y.P. Mao, L.H. Zhang, D.M. Li, H.F. Shi, Y.D. Liu, L.K. Cai, Electrochim. Acta 55, 7804 (2010)
[24] J.N. Jia, Y. Tang, B.F. Liu, D. Wu, N.Q. Ren, D.F. Xing, Bioresour. Technol. 144, 94 (2013)

[25] H. Richter, K. McCarthy, K.P. Nevin, J.P. Johnson, V.M. Rotello, D.R. Lovley, Langmuir 24, 4376 (2008)

[26] V.J. Watson, B.E. Logan, Biotechnol. Bioeng. 105, 489 (2010)

[27] V.B. Oliveira, M. Simões, L.F. Melo, A.M.F.R. Pinto, Biochem. Eng. J. 73, 53 (2013)

[28] A.L. Guerrero, K. Scott, I.M. Head, F. Mateo, A. Ginesta, C. Godinez, Fuel 89, 3985 (2010)

[29] A.G. Campo, J. Lobato, P. Cañizares, M.A. Rodrigo, F.J.F. Morales, Appl. Energy 101, 213 (2013)

[30] Z.H. Wen, S.Q. Ci, S. Mao, S.M. Cui, G.H. Lu, K.H. Yu, S.L. Luo, Z. He, J.H. Chen, J. Power Sources 234, 100 (2013)

[31] L.H. Liu, O. Tsyganova, D.J. Lee, A. Su, J.S. Chang, A.J. Wang, N.Q. Ren, Int. J. Hydrog. Energy 37, 15792 (2012)

[32] C.H. Feng, Q.Y. Wan, Z.S. Lv, X.J. Yue, Y.F. Chen, C.H. Wei, Biosens. Bioelectron. 26, 3953 (2011)

[33] M. Ghasemi, W.R.W. Daud, N. Mokhtarian, A. Mayahi, M. Ismail, F. Anisi, J. Alam, Int. J. Hydrog. Energy 38, 9525 (2013) 